\title{
Analisis Korelasi Faktor Resiko Kematian Di Ruang Isolasi Covid-19
}

\author{
Hirdes Harlan Yuanto ${ }^{a}$, Rudiyanto ${ }^{a}$, Ida Sri Surani Wiji Astuti ${ }^{b}$ \\ ${ }^{a}$ STIKES Banyuwangi, Banyuwangi, Indonesia \\ ${ }^{\mathrm{b}}$ Fakultas Kedokteran Universitas Jember, Jember, Indonesia \\ Email korespondensi: rudiyanto.roqy@gmail.com
}

\begin{abstract}
Introduction: Health workers and various other sectors are currently busy with handling world health cases of the Sars Cov-2 virus pandemic. The transmission of COVID-19 is very easy and dangerous, which is the cause of the increasing number of deaths. The large percentage of mortality rates for COVID-19 sufferers can be caused by internal factors and external factors. The purpose of this study was to analyze various factors that caused the death of COVID-19 sufferers. Method: This scientific report uses observational analytics with a retrospective study design. The research target of Covid-19 patients in the isolation room of the Graha Medika hospital in August - December 2020 was 437 respondents. The research sample amounted to 305 respondents who were selected with simple random sampling technique. The instruments that the researchers used in data collection were writing instruments and medical records of patients in the COVID-19 isolation room. Result: Most of the respondents were female, namely 161 respondents (52.8\%), Almost half of the respondents aged >60 years, namely 119 respondents (39\%), Almost all respondents underwent treatment for 1-5 days, namely 251 respondents (82.3\%), and most of the respondents had comorbidities, namely 228 respondents (74.8\%). Factors of age, sex, comorbidities, had a statistical value $(p<0.05)$ while the length of treatment was not related to the value ( $p>0.05)$. The most comorbid disease experienced by respondents was diabetes mellitus, and contributed to the death rate of 72 respondents $(23.6 \%)$. Conclusion: Immediate handling and appropriate intervention for elderly COVID-19 sufferers of various genders and especially those with comorbidities to minimize the mortality rate of COVID-19 sufferers.
\end{abstract}

Keywords: Covid-19, Death Factor, Isolation Room

\begin{abstract}
Abstrak
Pendahuluan: Tenaga kesehatan dan berbagai sektor lain pada saat ini tersibukkan dengan penanganan kasus kesehatan dunia pandemi virus Sars Cov-2 (Covid-19). Penularan covid-19 sangat mudah dan berbahaya menjadi penyebab meningkatnya angka kematian. Besarnya persentase angka mortalitas penderita covid-19 dapat disebabkan oleh faktor internal dan faktor eksternal. Arah penelitian ini yaitu teranalisisnya berbagai faktor yang menyebabkan kematian penderita covid -19. Metode: Laporan ilmiah ini menggunakan Analitik observasional dengan desain studi retrospektif. Sasaran penelitian pasien covid-19 di ruang isolasi rumah sakit Graha Medika pada bulan Agustus - Desember 2020 berjumlah 437 responden. Sampel penelitian berjumlah 305 responden yang dipilih dengaN teknik simple random sampling. Intrumen yang peneliti gunakan dalam pengambilan data berupa alat tulis dan rekam medik pasien ruang isolasi covid-19. Hasil: Sebagian responden berjenis kelamin perempuan yaitu 161 responden (52,8\%), Hampir setengah dari jumlah responden berusia $>60$ tahun yaitu 119 responden $(39 \%)$, Hampir seluruh responden menjalankan perawatan selama 1-5 hari yaitu 251 responden Hirdes Harlan Yuanto dkk, Korelasi Faktor Resiko Kematian Di Ruang Isolasi Covid-19 


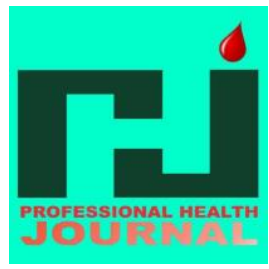

PROFESIONAL HEALTH JOURNAL

Volume 3 No. 1, Desember 2021 (Hal. 51-60)

https://www.ojsstikesbanyuwangi.com/index.php/PHJ

$(82,3 \%)$, dan sebagian besar responden mempunyai penyakit penyerta yaitu 228 responden $(74,8 \%)$. Faktor usia, jenis kelamin, penyakit penyerta, memiliki nilai hasil statistik $(\mathrm{p}<0,05)$ sedangkan lama perawatan tidak berhubungan dengan nilai $(p>0,05)$. Penyakit penyerta terbanyak yang dialami oleh responden yaitu diabetus mellitus, dan menyumbang angka kematian sebanyak 72 responden $(23,6 \%)$. Kesimpulan: Penanganan segera dan intervensi yang tepat pada penderita covid-19 dengan usia lanjut dengan berbagai jenis kelamin dan terkhusus yang memiliki penyakit penyerta untuk meminimalisasi angka kematian penderita covid-19.

Kata kunci: Covid-19, Faktor Kematian, Ruang Isolasi

\section{PENDAHULUAN}

Wabah Pandemi covid-19 menjadi permasalahan kesehatan dunia yang saat ini diperhatikan baik dari tenaga kesehatan maupun sektor lainnya (Purnamasari \& Raharyani, 2020). WHO menyatakan bahwa covid-19 merupakan virus yang memiliki virulensi tinggi dan telah lebih dari 121.000 infeksi di dunia, virus tersebut ditetapkan sebagai pandemi global (Ilpaj \& Nurwati, 2020). Data sebaran covid-19 di dunia pada 04 oktober 2021 mencapai 234.609.003 kasus dengan angka kematian 4.797.368 (WHO, 2021). Angka covid di Indonesia pada 04 Oktober 2021 sejumlah 4.220.206 kasus positif dan kasus meninggal 142.261 (Kemenkes RI, 2021). Data sebaran covid-19 di Jawa Timur pada 05 Oktober 2021 mencapai 396001 kasus yang terkonfirmasi positif dan 29464 kasus meninggal (FORUM COVID-19 JATIM, 2021). Data terkonfirmasi positif covid-19 pada bulan Oktober 2021 di Kabupaten Banyuwangi mencapai 13598 kasus, dan
1687 kasus meninggal (SATGAS COVID 19, 2021).

Covid-19 adalah penyakit menular dampak infeksi virus corona jenis Sars-Cov 2 yang muncul pada tahun 2019. Patogenesis covid-19 belum bisa ditentukan secara pasti namun para ahli mengasumsikan patogenesisnya hampir sama dengan virus penyebab gengguan respirasi lainnya (Purnamasari \& Raharyani, 2020). Saat virus covid-19 masuk ke saluran pernapasan, bisa terjadi gagal napas. Namun, berbagai gejala akan dialami oleh penjamu dari gejala ringan dan sedang yang tidak membutuhkan penanganan ekstra dan bisa sembuh dengan sendirinya. Berbeda halnya bagi penderita covid-19 yang memiliki berbagai penyakit penyerta seperti kardiovaskuler, penyakit pernafasan kronik, diabetes, dan kanker, akan mengalami gejala yang lebih berat (WHO, 2020).

Covid-19 saat ini menjadi penyebab utama meningkatnya angka kematian. Tingginya persentase data mortalitas penderita covid19 dipengaruhi 2 faktor, yaitu faktor fisik 


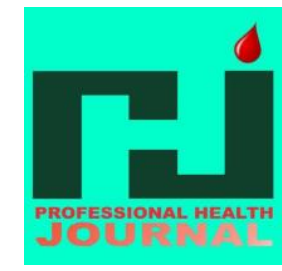

penderita, seperti penyakit bawaan dan kurangnya kesadaran individu pada virus tersebut, dan faktor dari luar individu berupa ketersediaan pelayanan yang kurang, peraturan pemerintahan yang tidak berlaku, dan lain - lain (Ilpaj \& Nurwati, 2020). Peneliti meninjau berbagai faktor internal yang belum banyak dilakukan penelitian, faktor yang seharusnya dapat dijaga kualitasnya agar pasien saat terinfeksi covid-19 tidak jatuh dalam kondisi kritis dan sampai terjadi kematian. Terpaparnya masyarakat oleh covid-19 saat sulit dihindari, namun upaya meminimalisir dampak saat terinfeksi virus covid-19 sangat mungkin dilakukan oleh berbagai sektor individu, keluarga, dan pemerintah. Diketahuinya faktor penyebab kematian pasien covid-19 akan menjadi bahan pertimbangan secara ilmiah dalam pengambilan keputusan dilingkup sosial dan interaksi secara nasional untuk pencegahan dampak penyebaran covid-19. Tujuan penelitian ini untuk melihat dan menganalisis berbagai faktor yang menyebabkan kematian pada penderita covid-19 diruang isolasi.

\section{METODE}

Analitik observasional yang peneliti gunakan dalam studi ilmiah ini dengan pendekatan studi retrospekstif. Rancangan
PROFESIONAL HEALTH JOURNAL Volume 3 No. 1, Desember 2021 (Hal. 51-60) https://www.ojsstikesbanyuwangi.com/index.php/PHJ studi ilmiah ini bertujuan untuk mengetahui faktor yang mempengaruhi kematian pasien covid-19. Tempat penelitian di rumah sakit Graha Medika Banyuwangi pada bulan Januari 2021. Objek penelitian adalah penderita covid -19 di ruang isolasi yang sembuh dan meninggal selama bulan Agustus - Desember 2020 sejumlah 437 orang. Sampel penelitian berjumlah 305 orang yg di pilih dengan tekhnik simple random sampling dengan kriteria inklusi: pasien rawat inap, usia lebih dari 17 tahun dan terdiagnosis covid-19. Kriteria ekslusi : pasien meninggal dalam perjalanan, data dalam rekam medik tidak lengkap. Intrumen yang digunakan yaitu alat tulis dan rekam medik pasien ruang isolasi covid-19. Data di analisis mengunakan uji korelasi Chi Square.

\section{HASIL}

Berdasarkan tabel 1 didapatkan sebagian responden berjenis kelamin perempuan yaitu 161 responden $(52,8 \%)$, Hampir setengah dari jumlah responden berusia $>60$ tahun yaitu 119 responden (39\%), Hampir seluruh responden menjalankan perawatan selama 1 - 5 hari yaitu 251 responden $(82,3 \%)$, dan sebagian besar responden mempunyai penyakit penyerta yaitu 228 responden $(74,8 \%)$.

Berdasarkan tabel 2 menunjukkan bahwa terdapat hubungan yang signifikan antara 
PROFESIONAL HEALTH JOURNAL

Volume 3 No. 1, Desember 2021 (Hal. 51-60)

https://www.ojsstikesbanyuwangi.com/index.php/PHJ

usia responden dengan status kehidupan (p $<0,05)$, sedangkan pada variabel jenis kelamin dengan status kehidupan didapatkan tidak ada hubungan yang siginifikan $(\mathrm{p}>0,05)$.

Berdasarkan tabel 3 menunjukkan adanya hubungan yang signifikan antara penyakit penyerta dengan status kehidupan responden $(\mathrm{p}<0,05)$. Penyakit penyerta terbanyak yang dialami oleh responden yaitu diabetus mellitus, dan menyumbang angka kematian sebanyak 72 responden $(23,6 \%)$.

Tabel 1. Data Demografi dan Komorbid Pasien Covid-19 ( $\mathrm{N}=305)$

\begin{tabular}{llcc}
\hline NO & Faktor Risiko & N & $\begin{array}{c}\text { Persentase } \\
(\boldsymbol{\%})\end{array}$ \\
\hline 1 & Jenis Kelamin & & \\
& Pria & 144 & 47,2 \\
& Wanita & 161 & 52,8 \\
\hline
\end{tabular}

\begin{tabular}{|c|c|c|c|}
\hline \multirow[t]{7}{*}{2} & \multicolumn{3}{|c|}{ Usia } \\
\hline & 18-20 Tahun & 0 & 0 \\
\hline & 21-30 Tahun & 20 & 6,6 \\
\hline & 31-40 Tahun & 28 & 9,2 \\
\hline & 41-50 Tahun & 49 & 16 \\
\hline & 51-60 Tahun & 89 & 29,2 \\
\hline & $>60$ Tahun & 119 & 39 \\
\hline \multirow[t]{4}{*}{3} & \multicolumn{3}{|l|}{ Lama Perawatan } \\
\hline & $1-5$ Hari & 56 & 82,3 \\
\hline & $6-10$ Hari & 41 & 13,4 \\
\hline & $11-15$ Hari & 13 & 4,3 \\
\hline \multirow[t]{13}{*}{4} & \multicolumn{3}{|l|}{ Penyakit Penyerta } \\
\hline & Tidak Ada & 77 & 25,2 \\
\hline & Hipertensi & 38 & 12,5 \\
\hline & $\mathrm{DM}$ & 74 & 24,3 \\
\hline & Henti Napas & 2 & 0,3 \\
\hline & GGK/CKD & 32 & 10,5 \\
\hline & Anemia & 8 & 2,6 \\
\hline & Kanker & 3 & 1 \\
\hline & $\mathrm{CHF}$ & 27 & 8,9 \\
\hline & CVA & 11 & 3,6 \\
\hline & Syok Kardiogenik & 2 & 0,7 \\
\hline & IMA & 2 & 0,7 \\
\hline & Diare & 1 & 0,3 \\
\hline
\end{tabular}

Leukimia

Hepatitis

Kolesistisis

TB

Serosis Hepatis

Cidera Kepala

Sepsis

Peritonitis

Tabel 2 Faktor Risiko Meninggal Pasien Covid-19 Berdasarkan Jenis Kelamin dan Usia $(\mathrm{N}=305)$

\begin{tabular}{|c|c|c|c|}
\hline $\begin{array}{c}\text { Variabe } \\
1\end{array}$ & $\begin{array}{l}\text { Hidup } \\
(\%)\end{array}$ & $\begin{array}{c}\text { Meninggal } \\
(\%)\end{array}$ & P-value \\
\hline \multicolumn{3}{|c|}{ Jenis Kelamin } & ,999 \\
\hline Laki-Laki & $34(11,1)$ & $110(36,1)$ & \\
\hline Perempuan & $123(40,3)$ & $38(12,5)$ & \\
\hline \multicolumn{3}{|c|}{ Usia (tahun) } & 000 \\
\hline $18-20$ & (0) & $-(0)$ & \\
\hline $21-30$ & $16(5,2)$ & $4(1,3)$ & \\
\hline $31-40$ & $21(6,9)$ & $7(2,3)$ & \\
\hline $41-50$ & $15(4,9)$ & $34(11,1)$ & \\
\hline $51-60$ & $14(4,6)$ & $75(24,6)$ & \\
\hline$>60$ & $6(2,0)$ & $113(37,0)$ & \\
\hline
\end{tabular}

Tabel 3 Faktor Risiko Meninggal Pasien Covid-19 Berdasarkan Komorbid $(\mathrm{N}=305)$

\begin{tabular}{lccc}
\hline \multicolumn{1}{c}{ Variabel } & $\begin{array}{c}\text { Hidup } \\
(\boldsymbol{\%})\end{array}$ & $\begin{array}{c}\text { Meninggal } \\
(\boldsymbol{\%})\end{array}$ & $\begin{array}{c}\text { P- } \\
\text { value }\end{array}$ \\
\hline Penyakit Penyerta & &, 001 \\
Tidak Ada & $64(21,0)$ & $13(4,3)$ & \\
Hipertensi & $3(1,0)$ & $35(11,5)$ & \\
DM & $2(0,7)$ & $72(23,6)$ & \\
Henti Napas & $0(0,0)$ & $1(0,3)$ & \\
GGK/CKD & $0(0,0)$ & $32(10,5)$ & \\
Anemia & $1(0,3)$ & $7(2,3)$ & \\
Kanker & $0(0,0)$ & $3(1,0)$ & \\
CHF & $0(0,0)$ & $27(8,9)$ & \\
CVA & $0(0,0)$ & $11(3,6)$ & \\
Syok & $0(0,0)$ & $2(0,7)$ & \\
Kardiogenik & & & \\
IMA & $0(0,0)$ & $2(0,7)$ & \\
Diare & $0(0,0)$ & $1(0,3)$ & \\
Leukimia & $0(0,0)$ & $4(1,3)$ & \\
Hepatitis & $1(0,3)$ & $2(0,7)$ & \\
Kolesistisis & $0(0,0)$ & $1(0,3)$ & \\
TB & $1(0,3)$ & $7(2,3)$ & \\
Serosis Hepati & $0(0,0)$ & $4(1,3)$ &
\end{tabular}




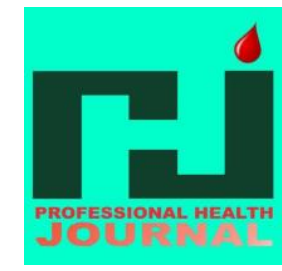

Cidera Kepala $0(0,0)$

Sepsis

$0(0,0)$

$4(1,3)$

Peritonitis

$0(0,0)$

PROFESIONAL HEALTH JOURNAL

Volume 3 No. 1, Desember 2021 (Hal. 51-60)

https://www.ojsstikesbanyuwangi.com/index.php/PHJ

\section{PEMBAHASAN}

\section{JENIS KELAMIN PENDERITA COVID-19}

Objek penelitian sebagian besar $(52,8 \%)$ didominasi oleh responden berjenis kelamin perempuan dengan porsi sebanyak 161 orang dengan tingkat kematian 123 responden (40,3\%). Bertolak belakang dengan hasil kajian oleh Zhou et al. (2020) bahwa penderita covid-19 berjenis kelamin laki - laki mendominasi angka kematian sebesar $62 \%$ dan analisis yang telah dilakukan oleh Susilo et al. (2020) menjelaskan laki - laki paling banyak terkena covid-19.

Cen et al. (2020) menjelaskan pria berisiko lebih tinggi terkena infeksi covid-19 dibandingkan dengan wanita, karena faktor kromosom dan hormonal. Pada wanita terdapat hormon seks seperti kromosom X dan progesteron, yang berperan penting dalam imunitas bawaan dan adaptif. Dibandingkan dengan wanita, pria biasanya memiliki lebih banyak keluar untuk berkerja, sehingga mereka lebih rentan terhadap penyakit (Hidayani, 2020). Lakilaki juga memiliki tingkat ACE2 yang lebih tinggi dibandingkan dengan perempuan, ACE2 merupakan reseptor untuk SARS-
CoV-2 (Zhou et al., 2020). Akan tetapi hal tersebut tidak menutup kemungkinan perempuan tidak terkena covid-19. Wanita lebih khawatir atau cemas dibandingkan dengan pria karena wanita lebih peka terhadap emosinya sendiri, yang akhirnya mempengaruhi rasa cemasnya (Kaplan \& Sadock, 2010). Kecemasan yang berlebihan dapat berdampak buruk pada tubuh, pikiran, dan bahkan menyebabkan penyakit fisik (Lama \& Cutler, 2014). Selain itu covid-19 sangat mudah menular pada kontak dekat, sebagaimana studi yang dilakukan oleh Cheng et al. (2020) mengatakan dari jumlah responden yang terkonfirmasi positif 151 responden merupakan kontak serumah dan 76 responden merupakan kontak keluarga tidak serumah. Hu et al. (2020) menjelaskan bahwa transmisi covid-19dapat melalui keluarga, dibuktikan pada keluarga kasus 13 dalam penelitiannya yang berjudul "Clinical Characteristics of 24 Asymptomatic Infections with COVID-19" ditemukan 4 orang yang terkonfirmasi positif dalam 1 keluarga. Sehingga tidak menutup kemungkinan perempuan juga memiliki risiko tinggi terkena penyakit covid-19.

Fakta yang peneliti dapatkan faktor yang mendukung tingginya angka mortalitas pada penderita covid-19 berjenis kelamin perempuan bahwa hampir seluruhnya 


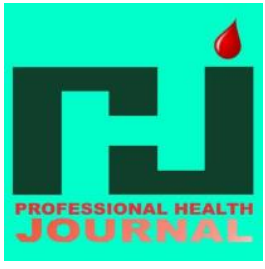

responden yang meninggal memiliki penyakit penyerta. Penyakit penyerta yang yang diderita pasien perempuan sebagian besar penyakit pembuluh darah, sesuai penelitian Kurniasih \& Setiawan, (2017) penderita penyakit kardiovaskuler lebih dari $60 \%$ diderita oleh perempuan. Penderita penyakit cardiovaskuler yang terinfeksi covid-19 10\% beriko mengalami kematian (Satria et al., 2020).

\section{USIA PENDERITA COVID-19}

Covid-19 diperkirakan memiliki masa inkubasi 3-14 hari dengan rata-rata masa tunas tiap kasus 5 hari (Satria et al., 2020). Selama pengentasan virus covid-19 didalam tubuh sel darah putih dan sistem kekebalan tubuh masih batas normal atau hanya sedikit menurun, dan tidak menimbulkan gangguan fisik (Tsatsakis et al., 2020). Disaat virus sudah masuk kedalam saluran pernafasan, gastrointestinal, dan kardiovaskuler tuuh akan merespon pengeluaran ACE2, maka tubuh akan mengalami gejala awal dalam kategori gejala ringan. Gejala berat akan segera dialami oleh penderita covid-19 hari ke-4 sampai ke-7 sejak munculnya gejala awal dengan keluhan yang dirasakan berupa panas tinggi, gangguan paru, sesak nafas, dan limfosit menurun, serta tanda peradangan mulai meningkat diikuti adanya gejala hiperkoagulabilitas (Cheng et al., 2020). Pada tahap peradangan, pasien betuh
PROFESIONAL HEALTH JOURNAL Volume 3 No. 1, Desember 2021 (Hal. 51-60) https://www.ojsstikesbanyuwangi.com/index.php/PHJ segera dilakukan penanganan agar tidak terjadi tahap peradangan yang tidak terkendali yang bisa menyebabkan badai sitokin, yang menyebabkan ARDS, sepsis, dan komplikasi lain, bahkan kematian (A. Susilo et al., 2020).

Penderita covid-19 yang meninggal dipengaru adanya faktor internal tubuh dan luar tubuh pasien (Wang et al., 2020). Salah satu faktor internal dominan berhubungan dengan mortalitas penderita covid-19 ialah usia(Wu et al., 2020). Usia lansia akan lebih rentan terhadap penyakit tertentu. Secara biologis pada usia lansia mengalami proses penuaan secara degenarative yang dapat mempengaruhi beberapa sistem pada tubuh salah satunya imunitas. Data yang tercatat di Indonesia pada halaman Kawal Covid-19 menunjukkan $40 \%$ kasus meninggal usia lebih dari 60 tahun. 56\% lainnya kisaran usia 50 tahun. Usia muda juga memiliki resiko kematian oleh infeksi virus covid-19, hal ini terbuktikan dengan angka kematian pada kelompok usia 40-49 tahun sebesar $12,5 \%$ dan angka kematian dibawah usia 40 tahun sebesar 6,25\% (Ilpaj \& Nurwati, 2020).

Hasil analisis statistik korelasi menunjukkan bahwa usia penderita berhubungan dengan kematian pada kasus covid-19 ( $\mathrm{p}<0,05)$, rentang usia terbanyak yang menyumbang angka kematian yaitu 
PROFESIONAL HEALTH JOURNAL

Volume 3 No. 1, Desember 2021 (Hal. 51-60)

https://www.ojsstikesbanyuwangi.com/index.php/PHJ

responden yang berusia lebih dari 60 tahun (37\%). Zhou et al. (2020) berpendapat bahwa usia yang lebih tua (lansia) lebih tinggi mengalami kematian akibat covid19. Usia yang lebih tua tercatat sebagai prediktor independen kematian pada SARS dan MERS.

Pada lansia terjadi proses menua yang ditandai dengan proses malfungsi jaringan sel dalam regenerasi dan mempertahankan fungsi normalnya, konpensasinya tubuh akan kehilangan fisiologisnya dalam memperbaiki kerusakan yang diderita (Azizah. Lilik, 2011). C. Susilo, (2018) dalam penelitiannya menyatakan bahwa pada usia 50 tahun seseorang akan mengalami penurunan produksi berbagai hormon yang menunjang proses regenerasi dan kesehatan organ. Dengan menurunnnya produktivitas berbagai hormon tubuh, saat terjangkit infeksi akan berisiko lebih tinggi mengalami kerusakan yang lebih fatal. Covid-19 menyebabkan infeksi pada paruparu dan menimbulkan lesi pada organ tersebut. Pada lansia proses pertahanan tubuh berkurang sehingga apabila covid-19 berhasil menginfeksi lansia tersebut maka proses perjalanan infeksi dapat semakin memberat, dan tubuh tidak dapat segera memperbaiki lesi pada paru-paru, sehingga apabila hal tersebut semakin memburuk menyebabkan paru-paru kehilangan fungsinya dan menyebabkan distres pernafasan pada penderita. Distres pernafasan yang berkelanjut menyebabkan pasokan oksigen pada tubuh tidak stabil atau menurun (menyebabkan hipoksia), dan hal tersebut apabila tidak teratasi akan mempengaruhi organ-organ tubuh lainnya dan dapat menyebabkan kematian (Herrmann et al., 2021).

\section{PENYAKIT}

PENYERTA

\section{PENDERITA COVID-19}

Faktor internal yang dapat menyebabkan kematian penderita covid-19selain usia yaitu riwayat penyakit pasien. Riwayat penyakit pasien yang dapat memperparah kondisi penderita covid-19diantaranya diabetes mellitus, asma, penyakit kardiovaskuler seperti hipertensi, gagal jantung, kardiomiopati, dan sebagainya (Ilpaj \& Nurwati, 2020).

Hasil analisis statistik memperlihatkan bahwa penyakit penyerta yang diderita pasien covid-19 berhubungan dengan kematian pasien covid-19 $(\mathrm{p}<0,05)$. Penyakit penyerta terbanyak yang dimiliki responden yaitu diabetes mellitus dan menjadi penyebab kematian sebanyak 72 responden $(23,6 \%)$. Sama hal nya dengan studi yang dilakukan oleh Mantovani, Byrne, Zheng, \& Targher (2020) didapatkan prevalensi pasien covid19dengan riwayat penyakit diabetes 


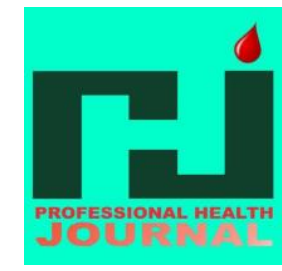

mellitus sebesar 14,34 \%. Wang, Li, Lu, \& Huang (2020) menjelaskan bahwa penderita covid-19 yang mempunyai pengalaman menderita diabetes mellitus berpeluang besar mengembangkan penyakit yang lebih serius atau kritis yang memerlukan perawatan intensif dua kali lebih tinggi. Penderita diabetes mellitus lebih tinggi meninggal akibat covid-19. Penyakit penyerta terbanyak kedua yaitu hipertensi dengan angka kematian 35 responden $(11,5 \%)$.

Tsatsakis et al. (2020) dalam hasil studi ilmiahnya menyatakan bahwa SARS-Cov berkonjugasi pada sel targetnya melalui Angiotensin Converting Enzyme 2 (ACE2), hasil ekskresi sel-sel epitel system pernafasan, gastrointestinal dan kardiovaskuler. Pada penderita yang pengobatan penyakit kencing manis dan hipertensi, ACE inhibitor dan Angiotensin II Receptor Blockers (ARB) mengalami peningkatan ACE2 pada tubuh. Kombinasi SARS-CoV2 dan ACE2 menyebabkan peningkatan ekskresi ACE2, yang dapat menyebabkan kerusakan sel alveolar. Cedera alveolar dapat memicu serangkaian reaksi sistemik dan bahkan kematian (Zhou et al., 2020). Hal tersebut menyebabakan pasien diabetes mellitus dan hipertensi mengalami risiko peningkatan
PROFESIONAL HEALTH JOURNAL Volume 3 No. 1, Desember 2021 (Hal. 51-60) https://www.ojsstikesbanyuwangi.com/index.php/PHJ pengembangan covid-19yang lebih parah dan fatal (kematian) (Fang et al., 2020). Fakta yang peneliti dapatkan dari studi ilmiah ini bahwa responden tanpa riwayat masalah kesehatan mempunyai kualitas hidup lebih tinggi, sebagaimana terlihat dari hasil penelitian responden yang tidak memiliki riwayat kesehatan sebanyak 64 responden $(21 \%)$ yang hidup dan hanya 13 responden yang meninggal (4,3\%). Hampir seluruh responden tampa riwayat masalah kesehatan berusianya $<60$ tahun yaitu 68 responden $(88,3 \%)$.

\section{KESIMPULAN DAN SARAN}

Kematian pada penderita covid-19 diruang Isolasi sebagain besar dipengaruhi oleh faktor internal pasien. Faktor yang berkaitan dari hasil analisis statistik meliputi jenis kelamin perempuan, usia $>60$ tahun, penyakit diabetes militus dan hipertensi.

Analisis lebih lanjut perlu dilakukan untuk melihat faktor diluar tubuh penderita covid19 yang mempengaruhi angka kematian pada penderita covid-19 yang dirawat di ruang isolasi, baik lingkungan fisik maupun lingkungan psikologis dan upaya lain yang sudah dilakukan oleh tim kesehatan ruang isolasi. 
PROFESIONAL HEALTH JOURNAL

Volume 3 No. 1, Desember 2021 (Hal. 51-60)

https://www.ojsstikesbanyuwangi.com/index.php/PHJ

\section{UCAPAN TERIMA KASIH}

Tim peneliti mengucapkan banyak terimakasih kepada jajaran pipinan di STIKES Banyuwangi, Fakultas Kedokteran UNEJ dan Rumah Sakit Graha Medika Banyuwangi serta para tenaga kesehatan yang ada di ruang isolasi covid-19 RS Graha Medika Banyuwangi.

\section{DAFTAR PUSTAKA}

Azizah. Lilik, M. (2011). Keperawatan Lanjut Usia. Graha Ilmu.

Cen, Y., Chen, X., Shen, Y., Zhang, X., Lei, Y., Xu, C., Jiang, W., Xu, H., Chen, \& Y; Zhu, J; Zhang, LL, Liu, Y. (2020). Risk Factors For Disease Progression In Patients With Mild To Moderate Coronavirus Disease 2019 A Multi Centre Observational. Clinical Microbiology and Infection.

Cheng, H. Y., Jian, S. W., Liu, D. P., Ng, T. C., Huang, W. T., \& Lin, H. H. (2020). Contact Tracing Assessment of COVID-19 Transmission Dynamics in Taiwan and Risk at Different Exposure Periods before and after Symptom Onset. JAMA Internal Medicine, 180(9), 1156-1163. https://doi.org/10.1001/jamainternmed.202 0.2020

Fang, L., Karakiulakis, G., \& Roth, M. (2020). Are patients with hypertension and diabetes mellitus at increased risk for COVID-19 infection? The Lancet Respiratory Medicine, 8(4), e21. https://doi.org/10.1016/S2213-

2600(20)30116-8

FORUM COVID-19 JATIM. (2021). JATIM Tanggap Covid - 19. FORUM COVID-19 JATIM.

Herrmann, M. L., Hahn, J. M., Walter-
Frank, B., Bollinger, D. M., Schmauder, K., Schnauder, G., Bitzer, M., Malek, N. P., Eschweiler, G. W., \& Göpel, S. (2021). COVID-19 in persons aged 70+ in an early affected German district: Risk factors, mortality and post-COVID care needs-A retrospective observational study of hospitalized and non-hospitalized patients. PLoS ONE, $16(6$ June), 1-11. https://doi.org/10.1371/journal.pone.02531 54

Hidayani, W. R. (2020). Faktor Faktor Risiko Yang Berhubungan Dengan COVID 19: Literature Review. Jurnal Untuk Masyarakat Sehat (JUKMAS), 4(2), 120134.

https://doi.org/10.52643/jukmas.v4i2.1015

Hu, Z., Song, C., Xu, C., Jin, G., Chen, Y., $\mathrm{Xu}, \mathrm{X}$. , Ma, H., Chen, W., Lin, Y., Zheng, Y., Wang, J., \& Hu, Z. (2020). Clinical characteristics of 24 asymptomatic infections with COVID- 19. Sci China Life Sci., 63(5), 706-711.

Ilpaj, S. M., \& Nurwati, N. (2020). Analisis Pengaruh Tingkat Kematian Akibat Covid19 Terhadap Kesehatan Mental Masyarakat Di Indonesia. Focus: Jurnal Pekerjaan Sosial, 3(1), 16. https://doi.org/10.24198/focus.v3i1.28123

Kaplan, H. I., \& Sadock, B. J. (2010). Retardasi Mental dalam Sinopsis Psikiatri. Binarupa Aksara.

Kemenkes RI. (2021). Kesiapan Menghadapi Infeksi COVID-19. Kemenkes RI.

Kurniasih, I., \& Setiawan, M. R. (2017). Analisis Faktor Risiko Kejadian Hipertensi di Puskesmas Srondol Semarang Periode Bulan September - Oktober 2011. Jurnal Kedokteran Muhammadiyah, 1(2), 54-59.

Lama, D., \& Cutler, H. C. (2014). The Art of Happiness. Awareness Publication. 


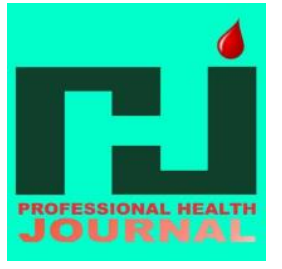

Mantovani, A., Byrne, C. D., Zheng, M. H., \& Targher, G. (2020). Diabetes as a Risk Factor for Greater COVID-19 Severity and in-Hospital Death: A Meta-Analysis of Observational Studies. Nutrition, Metabolism and Cardiovascular Diseases, 80(8), 1236-1248.

Purnamasari, I., \& Raharyani, A. E. (2020). Tingkat Pengetahuan Dan Perilaku Masyarakat Kabupaten Wonosobo Tentang Covid -19. Jurnal Ilmiah Kesehatan, 3(1), 33-42.

SATGAS COVID - 19. (2021). Data Terkini Covid - 19 di Banyuwangi. BANYUWANGIKAB.

Satria, R. M. A., Tutupoho, R. V., \& Chalidyanto, D. (2020). Analisis Faktor Risiko Kematian dengan Penyakit Komorbid Covid-19. Jurnal Keperawatan Silampari, 4(1), 48-55. https://doi.org/10.31539/jks.v4i1.1587

Susilo, A., Rumende, C. M., Pitoyo, C. W., Santoso, W. D., Yulianti, M., Herikurniawan, H., Sinto, R., Singh, G., Nainggolan, L., Nelwan, E. J., Chen, L. K., Widhani, A., Wijaya, E., Wicaksana, B., Maksum, M., Annisa, F., Jasirwan, C. O. M., \& Yunihastuti, E. (2020). Coronavirus Disease 2019: Tinjauan Literatur Terkini. Jurnal Penyakit Dalam Indonesia, 7(1), 45. https://doi.org/10.7454/jpdi.v7i1.415

Susilo, C. (2018). Identifikasi Faktor Usia, Jenis Kelamin Dengan Luas Infark Miokard Pada Penyakit Jantung Koroner (Pjk) Di Ruang Iccu Rsd Dr. Soebandi Jember. The Indonesian Journal of Health Science, 6(1), $1-7$.

Tsatsakis, A., Calina, D., Falzone, L., Petrakis, D., Mitrut, R., Siokas, V., Pennisi, M., Lanza, G., Libra, M., Doukas, S. G., Doukas, P. G., Kavali, L., Bukhari, A., Gadiparthi, C., Vageli, D. P., Kofteridis, D. P., Spandidos, D. A., Paoliello, M. M. B.,
PROFESIONAL HEALTH JOURNAL

Volume 3 No. 1, Desember 2021 (Hal. 51-60) https://www.ojsstikesbanyuwangi.com/index.php/PHJ
Aschner, M., \& Docea, A. O. (2020). SARS-CoV-2 pathophysiology and its clinical implications: An integrative overview of the pharmacotherapeutic management of COVID-19. Food and Chemical Toxicology, 146(September), 111769.

https://doi.org/10.1016/j.fct.2020.111769

Wang, B., Li, R., Lu, Z., \& Huang, Y. (2020). Does Comorbidity Increase the Risk of Patients with Covid-19: Evidence from Meta-Analysis. Aging, 12(7), 6049-6057.

WHO. (2020). Corona Virus (Covid-19). WHO.

WHO. (2021). WHO Coronavirus (COVID19) Dashboard. WHO.

Wu, C., Chen, X., Cai, Y., Xia, J., Zhou, X., Xu, S., Huang, H., Zhang, L., Zhou, X., Du, C., Zhang, Y., Song, J., Wang, S., Chao, Y., Yang, Z., Xu, J., Zhou, X., Chen, D., Xiong, W., ... Song, Y. (2020). Risk Factors Associated with Acute Respiratory Distress Syndrome and Death in Patients with Coronavirus Disease 2019 Pneumonia in Wuhan, China. JAMA Internal Medicine, 180(7),

934-943. https://doi.org/10.1001/jamainternmed.202 0.0994

Zhou, F., Yu, T., Du, R., Fan, G., Liu, Y., Liu, Z., Xiang, J., Wang, Y., Song, B., Gu, X., Guan, L., Wei, Y., Li, H., Wu, X., Xu, J., Tu, S., Zhang, Y., Chen, H., \& Cao, B. (2020). Clinical course and risk factors for mortality of adult inpatients with COVID19 in Wuhan, China: a retrospective cohort study. The Lancet, 395(10229), 1054-1062. https://doi.org/10.1016/S01406736(20)30566-3 